Article

\title{
Fruit Quality Properties of the Local Apple Varieties of Anatolia
}

\author{
İdris Macit ${ }^{1}$, Erol Aydın ${ }^{1}$, Akgul Tas ${ }^{2}\left[\right.$ and Muttalip Gundogdu ${ }^{3, *} \mathbb{C}$ \\ 1 Republic of Turkey Ministry of Agriculture and Forestry, Black Sea Agricultural Research Institute, \\ 55000 Samsun, Turkey; idris.macit@tarim.gov.tr (İ.M.); aydin.erol@tarimorman.gov.tr (E.A.) \\ 2 Department of Plant and Animal Production, Seben İzzet Baysal Vocational School, Bolu Abant Izzet Baysal \\ University, 14750 Seben Bolu, Turkey; akgultas1438@gmail.com \\ 3 Department of Horticulture, Faculty of Agriculture, Bolu Abant Izzet Baysal University, 14030 Bolu, Turkey \\ * Correspondence: gundogdumuttalip@gmail.com
}

check for updates

Citation: Macit, İ.; Aydın, E.; Tas, A.; Gundogdu, M. Fruit Quality

Properties of the Local Apple Varieties of Anatolia. Sustainability 2021, 13, 6127. https://doi.org/ $10.3390 /$ su13116127

Academic Editor:

Alessandra Durazzo

Received: 18 May 2021

Accepted: 26 May 2021

Published: 28 May 2021

Publisher's Note: MDPI stays neutral with regard to jurisdictional claims in published maps and institutional affiliations.

Copyright: (C) 2021 by the authors Licensee MDPI, Basel, Switzerland. This article is an open access article distributed under the terms and conditions of the Creative Commons Attribution (CC BY) license (https:/ / creativecommons.org/licenses/by/ $4.0 /)$.

\begin{abstract}
The importance of biochemical content of fruits in human health and nutrition is understood more and more day by day. In this study, new local varieties were added to apple genetic resources and the correlation between biochemical contents and agro-morphological properties of fruits belonging to them was revealed. It was observed that the total phenolics amount varied between 20.13 ("Bag") mg GAE kg-1 and 80.59 ("Yeşil") mg GAE kg-1. The highest total antioxidant capacity was determined as $90.96 \%$ in "Yeşil" variety. Potassium (K) content, which is among the macronutrients, was determined as the highest value in "Bağ" variety $\left(7993.31 \mathrm{mg} \mathrm{kg}{ }^{-1}\right)$ and in "Zuza" variety (7983.31 $\mathrm{mg} \mathrm{kg}^{-1}$ ). It was determined that the Fe content (iron) varied between as $14.17 \mathrm{mg} \mathrm{kg}^{-1}$ ("Zuza") and $5.75 \mathrm{mg} \mathrm{kg}^{-1}$ ("Bağ") and was higher than other micronutrients. In the light of the results obtained in this study, it was concluded that fruits belonging to new local apple varieties are rich in biochemical contents and these varieties can be used as genetic resources in plant breeding studies.
\end{abstract}

Keywords: apple; fruit; antioxidant; phenolic; nutrients

\section{Introduction}

Anatolia is accepted as the homeland of many horticultural crops [1-5]. Turkey has many wild and local apple genetic resources. This species of richness offers different usage possibilities for fruit breeders [2]. Anatolia is a key country in terms of global biodiversity in terms of its location at the crossroads of three different continents. It also has a complex topography and geomorphology. With these features, it contains a wide variety of habitats and species, especially a rich flora. Turkey's wealth of biodiversity reveals the importance in global terms. Three of the thirty-four intensive biodiversity hotspots on Earth (the Caucasus, the Mediterranean and Irano-Anatolian) intersect in Turkey [6-8]. Phenology, morphology and biochemical contents of fruits are affected by many factors such as ecological conditions, cultural practices and genetic features [9]. Apple is among the fruits that show great variety in morphological and biochemical diversity [2] and previous studies conducted on apples clearly indicate the rich biochemical content of its fruits. Kschonsek et al. [10] determined that quercetin glycosides were the main polyphenols in the peel and phenolic acids in the apple fruit flesh. The same researchers reported that flavones are predominant in the apple peel, followed by flavanols, phenolic acids and dihydrochalcone phloridzin [10]. Due to the antioxidant properties of the polyphenols contained in apple fruits, it is thought that they may help reduce the risk of obesity, cancer, hypertension, diabetes and cardiovascular diseases [11,12]. Vitamin C, a powerful antioxidant source, has been associated with many pharmacological applications, the best example of which is the shortening of the common cold [13]. Phenolic compounds, which are secondary metabolites, are structures with low molecular weight. They are found in small or large amounts in fruits and vegetables and show higher antioxidative effects 
than other bioactive compounds. It has been reported by many researchers that phenolic compounds have positive effects on human health [14]. Phenolic compounds have been reported to inhibit cancer cells, have antimutagenic activity and blood pressure lowering effect, and may help to reduce cardiovascular risk [15]. In addition, it is effective in the formation of the flavor of fruits or vegetables and the products obtained from these foods, and especially in the formation of a bitter taste in the mouth. Phenolic substances make up the distinctive color of fruits and vegetables [16,17]. Apple is a rich source of phenolic compounds and antioxidants [18]. Jakobek et al. [19] determined that old apple varieties ('Pisanika', 'Kanada', 'Crvenka', 'Lještarka', 'Kolerova sr` cika', 'Ivanlija', 'Boži'cnica 2', 'Wild apple', 'Adamova zvijezda', and 'Zelenika') have rich polyphenol contents and fruits of these varieties can be used in value-added foods. In different studies, it was reported that geographical conditions, and genetic characteristics have an effect on the polyphenol contents of apple varieties [20]. It was shown in some studies that rootstocks in fruit growing have a great influence on some important tree and fruit characteristics such as productivity, flower formation, mineral nutrition, and SSC [21].

Macro- and micronutrients, which are important in human health and nutrition, are abundant in apples. Apple is a type of fruit that has extremely rich potential in terms of macro and micro elements such as nitrogen, phosphorus, potassium, calcium, magnesium, sulfur, iron, boron, zinc, manganese, copper, and molybdenum [22]. In some studies, the importance of a balanced diet has been emphasized in order to improve and protect the quality characteristics of fruits $[23,24]$. It has been reported that nitrogen, calcium, and potassium are among the elements that most affect the quality characteristics of apple fruits [25]. However, in different studies, it has been emphasized that the ratio of nutrients is more important than the concentration of individual mineral elements on fruit quality [26]. In the study conducted by Dris and Niskanen [27], the status of macronutrient content ( $\mathrm{N}$, $\mathrm{P}, \mathrm{K}, \mathrm{Ca}$ and $\mathrm{Mg}$ ) during the development of apple fruits was revealed, and it was reported that there was a significant positive correlation between $\mathrm{P}$ and Ca concentrations in early and normally harvested fruits.

The replacement of local apple varieties with commercial apple varieties in recent years has led to a dramatic loss of genetic diversity in terms of adaptation, disease tolerance and fruit quality [28]. In the present study, the total antioxidant activity, phenolic substances content, macro and micronutrient elements and pomological properties of fruits belonging to 8 old local apple varieties were determined. As a result of the selection, the varieties with prominent fruit weights, sizes and biochemical properties were included in the scope of this study. Agro-morphological properties and detailed biochemical analyzes of the local apple varieties were determined first time on these materials in the literature.

\section{Materials and Methods}

\subsection{Plant Material and Agromorphological Properties}

In this study, selection breeding was made in the Artvin (Turkey) region and 8 local apple varieties that stand out in terms of different characteristics were selected (Table 1). The climate data of the province of Artvin where the research was conducted for the years 2017, 2018 and 2019 were given in Tables S1 and S2 [29]. It was observed that the apple varieties differ morphologically and biochemically from each other. It is thought that genetic characteristics and ecological factors affect these differences and as a result, fruits ripen at different times. In the present study, genotypes that grow in wild form in nature were selected. The research was conducted for three years in 2017, 2018 and 2019. In the study, 20 fruits from each local variety were used for pomological and biochemical analysis. Biochemical analyses were performed in triplicate. 
Table 1. Local names, origin and phonological properties of local apple varieties grown in the Artvin province (Average of data for 2017, 2018 and 2019).

\begin{tabular}{|c|c|c|c|c|c|c|c|c|}
\hline Varieties & District & Village & Altitude (m) & $\begin{array}{l}\text { Tree Age } \\
\text { (Years) }\end{array}$ & Blooming Date & Harvesting Date & Fruit Color & $\begin{array}{c}\text { Yield } \\
\left(\mathrm{kg} \mathrm{Tree}^{-1}\right)\end{array}$ \\
\hline Uzun & Yusufeli & Tekkale & 654 & 30 & 3-7 April & 15-20 Sept. & Yellowish & 100 \\
\hline Bağ & Şavşat & Meydancık & 1390 & 30 & 8-12 April & $20-25$ Aug. & Red & 150 \\
\hline Zuza & Ardanuç & Meşeköy & 1459 & 70 & 1-5 April & 25-30 Sept. & Yellow & 250 \\
\hline Beray & Borçka & Camili & 833 & 25 & 10-15 April & $15-25$ Oct. & Red & 80 \\
\hline Yeşil & Arhavi & Ortacalar & 430 & 10 & 5-10 April & 15-20 Sept. & Green & 80 \\
\hline Süt & Merkez & Seyitler & 587 & 20 & 1-5 April & 25-30 Sept. & Yellow & 70 \\
\hline Yazlik & Merkez & Seyitler & 596 & 15 & 1-3 April & $20-25$ July & Yellow & 120 \\
\hline Köşeli & Şavşat & Meydancık & 1398 & 10 & 6-10 April & 5-10 Oct. & Red & 80 \\
\hline
\end{tabular}

In the selection study, genotypes superior to fruit pomology and biochemical content were selected. The selected apple genotypes were diverse from each other in terms of fruit properties and biochemical characteristics, and all genotypes had attractive fruits, high yield capacity and were free of pests and disease characteristics. Apple fruit samples taken from each apple tree were labeled and put into boxes placed in appropriate containers and immediately transferred to the laboratory. Fruit samples to be used for biochemical analysis were kept in ultra-low temperature chest freezers at $-80{ }^{\circ} \mathrm{C}$ until analysis. Some pomological properties of apple varieties were investigated. The average fruit weight of 10 fruits taken randomly from each variety (with $0.01 \mathrm{~g}$ sensitive scales), fruit height, fruit width (with $0.01 \mathrm{~mm}$ sensitive caliper) and $\mathrm{pH}$ (with $\mathrm{pH}$ meter) were determined. The measurement of SSC (\%) was performed by a digital refractometer (PAL-1, McCormick Fruit Tech., Yakima, WA, USA). The juice of the fruit was stirred with distilled water at the ratio of 1:1 for titratable acidity. For titrating the solution, $0.1 \mathrm{~N} \mathrm{NaOH}$ (sodium hydroxide) was used.

\subsection{Nutrient Analysis}

The $\mathrm{N}$ analysis was performed as reported by Horneck et al. [30], and the P analysis was performed with the method of Kacar [31]. Other macro and micro elements were measured by atomic absorption spectrometry [31].

\subsection{Determination of Total Antioxidant Capacity and Total Phenolic}

DPPH activity was calculated by the method of Molyneux [32]. In the present study, $3 \mathrm{~mL}$ of fruit sample extracted with $70 \%$ ethanol and $1 \mathrm{~mL}$ of DPPH solution prepared with $70 \%$ ethanol was transferred to a tube and shaken with a vortex. It was then kept in the dark for $30 \mathrm{~min}$ and read at $517 \mathrm{~nm}$ in the spectrophotometer. The absorbance value of the DPPH radical was read as a control. DPPH Activity Inhibition (\%) was calculated using the formula below.

$$
\text { DPPH Activity Inhibition }(\%)=((\text { AControl }- \text { ASample }) / \text { AControl }) \times 100
$$

Sample extraction to measure TPC (total phenolic content); after adding $20 \mathrm{~mL}$ of $80 \%$ ethyl alcohol on $5 \mathrm{~g}$ of apple, samples were crushed in a mortar. Then, samples were separated from the pulp via centrifuging at $12,000 \times \mathrm{g}$ at $4{ }^{\circ} \mathrm{C}$ for $35 \mathrm{~min}$. The total phenol was detected using an automated UV-Vis spectrophotometer (Shimadzu, Kyoto, Japan) by adhering to the principles established by Singleton and Rossi [33]. The results were presented as $\mathrm{mg} \mathrm{kg}^{-1} \mathrm{GAE}$ (gallic acid equivalent) fresh weight (fw). Vitamin C content of fruits was detected with a modified HPLC procedure suggested by Cemeroglu [34]. Fruit extracts (50 g) supplemented with $2.5 \%\left(\mathrm{w} \mathrm{v}^{-1}\right)$ metaphosphoric acid (Sigma, Merck, Darmstadt, Germany, M6285, 33.5\%), then these extracts were centrifuged at $6500 \mathrm{rpm}$ for $10 \mathrm{~min}$ at $4{ }^{\circ} \mathrm{C}$ temperature. $0.5 \mathrm{~mL}$ of the mixture brought to a final volume of $10 \mathrm{~mL}$ with \% $2.5\left(\mathrm{w} \mathrm{v}^{-1}\right)$ metaphosphoric acid. Supernatants were filtered with a $0.45 \mu \mathrm{m}$ PTFE syringe filter (Millipore Millex-HV Hydrophilic PVDF, Millipore, MA, USA). C18 column (Phenomenex Luna C18, $250 \times 4.60 \mathrm{~mm}, 5 \mu$, MA, USA) was used to identify ascorbic 
acid at $25^{\circ} \mathrm{C}$. Double distilled water with $1 \mathrm{~mL} \mathrm{~min}^{-1}$ flow rate and $\mathrm{pH}$ of 2.2 (acidified with $\mathrm{H}_{2} \mathrm{SO}_{4}$ ) was used as a mobile phase. Spectral measurements were made at $254 \mathrm{~nm}$ wavelength using a DAD detector. Different standards of L-ascorbic acid (Sigma A5960, Sigma, Merck, Darmstadt, Germany) (50, 100, 500, 1000, and 2000 ppm) were used for quantification of ascorbic acid readings.

\subsection{Statistical Analysis}

Descriptive statistics, normal distribution tests, correlation analysis, and one-way variance analysis were performed with the SAS 9.4 program (Statistical Analysis System, Raleigh, NC, USA). The Duncan test was used as a multiple comparison test to express the differences between the average values. In $\mathrm{R}$ software, the principal component analysis was used for all variables with the ggplot2 and factoextra packages [35].

\section{Results and Discussion}

\subsection{SSC, $p H$, Acidity and Pomological Properties}

Statistically significant differences were found between local apple varieties in terms of fruit characteristics and biochemical properties (Table 2). When the average fruit weights of the genotypes were examined according to the results of the study, the highest value was determined in "Yaz" (269.32 g) variety and the lowest value was in "Zuza" (27.56 g) variety. The highest Total Soluble Solids (TSS) value was found in "Zuza" variety $(8.93 \%)$ and the lowest value was found in "Bağ" variety $(7.07 \%)$. In this study, it was determined that the yield and age of apple varieties affect the pomological properties of fruits. In addition, the altitude and ecological conditions of the areas where the varieties are selected affect the morphological, phenological, pomological and biochemical properties of the trees [36].

Table 2. TSS, pH, acidity and pomological properties of apple varieties.

\begin{tabular}{|c|c|c|c|c|c|c|}
\hline Varieties & Fruit Weight (g) & Fruit Width (mm) & Fruit Length (mm) & TSS (\%) & Total Acidity (\%) & $\mathrm{pH}$ \\
\hline Bağ & $88.53 \pm 1.94 c^{*}$ & $68.24 \pm 1.28 \mathrm{c}$ & $67.48 \pm 1.43 b$ & $7.07 \pm 0.18 c$ & $0.44 \pm 0.02 \mathrm{bc}$ & $4.03 \pm 0.02 b$ \\
\hline Beray & $90.99 \pm 2.92 c$ & $59.30 \pm 2.13 \mathrm{~d}$ & $59.42 \pm 1.96 \mathrm{c}$ & $7.40 \pm 0.23 c$ & $0.38 \pm 0.01 \mathrm{de}$ & $3.93 \pm 0.06 \mathrm{bc}$ \\
\hline Köşeli & $101.08 \pm 1.42 b c$ & $94.10 \pm 0.99 a$ & $78.82 \pm 1.13 \mathrm{a}$ & $7.93 \pm 0.18 b$ & $0.40 \pm 0.01 \mathrm{~cd}$ & $4.18 \pm 0.06 \mathrm{a}$ \\
\hline Süt & $95.1 \pm 1.68 \mathrm{c}$ & $81.33 \pm 2.06 b$ & $71.73 \pm 2.39 b$ & $8.13 \pm 0.18 b$ & $0.36 \pm 0.01 \mathrm{e}$ & $4.01 \pm 0.04 \mathrm{~b}$ \\
\hline Uzun & $127.1 \pm 2.43 \mathrm{~b}$ & $62.09 \pm 0.22 \mathrm{~d}$ & $69.52 \pm 1.36 b$ & $8.83 \pm 0.09 \mathrm{a}$ & $0.38 \pm 0.01 \mathrm{de}$ & $3.95 \pm 0.02 b c$ \\
\hline Yaz & $269.32 \pm 29.29 \mathrm{a}$ & $92.22 \pm 3.17 \mathrm{a}$ & $69.63 \pm 1.60 b$ & $8.07 \pm 0.18 b$ & $0.39 \pm 0.01 \mathrm{de}$ & $3.87 \pm 0.07 c$ \\
\hline Yeşil & $89.08 \pm 1.85 c$ & $61.30 \pm 1.98 \mathrm{~d}$ & $58.93 \pm 1.03 c$ & $7.07 \pm 0.18 c$ & $0.45 \pm 0.02 \mathrm{ab}$ & $4.03 \pm 0.02 \mathrm{~b}$ \\
\hline $\mathrm{Zuza}$ & $27.56 \pm 1.71 \mathrm{~d}$ & $18.69 \pm 1.31 \mathrm{e}$ & $20.19 \pm 0.80 \mathrm{~d}$ & $8.93 \pm 0.18 \mathrm{a}$ & $0.49 \pm 0.01 \mathrm{a}$ & $3.72 \pm 0.05 \mathrm{~d}$ \\
\hline
\end{tabular}

* The difference among the means indicated with the same lower case letter in columns was not significant $(p \leq 0.05)$.

The total acidity and $\mathrm{pH}$ values varied between $0.49-0.36 \%$ and $4.18-3.72$, respectively (Table 2). TSS and acidity have been reported to be important taste indicators for fruits [37]. In the study conducted by Öztürk and Öztürk [38] on apple, TSS values ranged from $10.46 \%$ to $13.45 \%$. Boyac1 [39] found the highest value (15.4\%) in Mondial Gala apple variety in terms of TSS, and the lowest value $(11.16 \%)$ in Granny Smith and $(11.53 \%)$ in Red Chief cultivars. In the study conducted by Karşı and Aslantaş [40], the TSS content varied between $7.73 \%$ (Hüryemez) and $14.60 \%$ (Golden Delicious). In another study, they noted that the content of TSS ranged from 10.24\% (Granny Smith) to 12.07\% (Royal Gala) [41]. Boyac1 et al. [38] conducted to determine the biochemical content of apple fruits, they determined the $\mathrm{pH}$ value as 4.03 in Red Chief variety and 3.31 in Granny Smith variety. Gündoğdu et al. [42] reported that local apple varieties have rich in biochemical ingredients. In a study conducted by Hajnajari et al. [43] on summer apple to determine fruit weight and size in Iran, fruit weight ranged from $11.47 \mathrm{~g}$ to $98.50 \mathrm{~g}$. Similar studies were done by other researchers $[2,22]$. In this study, it was observed that our findings of fruit sizes and biochemical properties are generally similar to the results of other studies. The dissimilar results are thought to be due to differences in ecological conditions, cultural practices, and genetic factors. 


\subsection{Bioactive Compounds}

The total phenolic amount of apple varieties was examined, and statistically significant differences were determined between varieties. Phenolic substances are biochemical compounds that are effective in many physiological events in plants as well as on the quality characteristics of fruits such as taste and aroma. While the highest phenolic amount was found as $80.59 \mathrm{mg} \mathrm{GAE} \mathrm{kg}^{-1} \mathrm{fw}$ in "Beray" variety, the lowest phenolic amount was found as $16.27 \mathrm{mg} \mathrm{GAE} \mathrm{kg}^{-1} \mathrm{fw}$ in "Yeşil" variety (Table 3). Öztürk et al. [44] determined the total phenol content as $32.30 \mathrm{mg} \mathrm{GAE} \mathrm{kg}^{-1}$ in Granny Smith variety and $65.30 \mathrm{mg} \mathrm{GAE} \mathrm{kg}^{-1}$ in Mondial Gala variety. In the study in which the total phenolic con-centration amount in the skin of apple fruits was determined, it was stated that the total phenolic amount varied between 502.2 and $1294.9 \mu^{-1} \mathrm{~g} \mathrm{~g}^{-1}$ [45]. Biochemical contents of fruits differ in peel and fruit pulp. Michailidis et al. [46] investigated biochemical contents of peeled and unpeeled fruits. In the same research, a higher rate of soluble solids concentration, carotenoids, dry matter, hydroxycinnamic acids, and flavonols were found in the unpeeled Gala apple cultivars. In the study conducted by Karagiannis et al. [47], It has been reported that high altitude affects several basic color parameters such as redness and color index in the ripening of apple fruits. Bouayed et al. [48], reported that the total phenolic substance content was between 120-180 mg $100 \mathrm{~g}^{-1}$ in apple. Abac1 and Sevindik [49] compared the total amount of phenolic matter in the fruit peel and fruit flesh of apple varieties in their study. The same researchers found the highest total (TP) phenolic in the fruit peel of the Uruset apple variety (578.7 mg $100 \mathrm{~g}^{-1}$ ). They reported that the lowest TP was in the fruit flesh of the Kanevoz apple variety $\left(46.9 \mathrm{mg} 100 \mathrm{~g}^{-1}\right)$. Gündoğdu et al. [42] reported higher content of catechin, chlorogenic acid, gallic acid, phlorizin and rutin than other phenolic compounds in their study on apple genotypes.

Table 3. Total phenolic, total antioxidant activity, and vitamin $C$ contents of apple varieties.

\begin{tabular}{|c|c|c|c|}
\hline Varieties & $\begin{array}{c}\text { Total Phenolic } \\
\left(\mathrm{mg} \mathrm{GAE} \mathrm{kg}{ }^{-1} \text { fw) }\right.\end{array}$ & $\begin{array}{l}\text { Total Antioxidant } \\
\text { Activity (\%) }\end{array}$ & 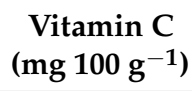 \\
\hline Bağ & $20.13 \pm 0.48 \mathrm{e}^{*}$ & $55.63 \pm 0.80 \mathrm{e}$ & $5.76 \pm 0.01 b$ \\
\hline Beray & $80.59 \pm 1.91 \mathrm{a}$ & $72.31 \pm 1.22 \mathrm{c}$ & $3.66 \pm 0.13 \mathrm{~d}$ \\
\hline Köşeli & $34.22 \pm 0.27 c$ & $28.57 \pm 0.78 \mathrm{f}$ & $2.31 \pm 0.02 \mathrm{f}$ \\
\hline Süt & $50.59 \pm 0.43 b$ & $23.2 \pm 0.28 \mathrm{~g}$ & $2.38 \pm 0.01 \mathrm{f}$ \\
\hline Uzun & $33.09 \pm 3.45 c$ & $78.30 \pm 1.16 b$ & $5.52 \pm 0.05 c$ \\
\hline Yaz & $28.09 \pm 0.36 \mathrm{~d}$ & $28.37 \pm 0.42 \mathrm{f}$ & $2.56 \pm 0.10 \mathrm{e}$ \\
\hline Yeşil & $16.27 \pm 0.22 \mathrm{f}$ & $90.96 \pm 1.20 \mathrm{a}$ & $7.66 \pm 0.24 \mathrm{a}$ \\
\hline Zuza & $17.40 \pm 0.29 \mathrm{f}$ & $59.43 \pm 0.49 \mathrm{~d}$ & $2.52 \pm 0.01 \mathrm{e}$ \\
\hline
\end{tabular}

* The difference among the means indicated with the same lower case letter in columns was not significant $(p \leq 0.05)$.

There were also statistically significant differences between the studied apple varieties in terms of antioxidant activity and vitamin $C$ content of fruits. In this study, the highest antioxidant activity was determined as $90.96 \mathrm{mg} 100 \mathrm{~g}^{-1}$ in the "Yeşil" variety. In addition, the lowest antioxidant activity was found in "Süt" $\left(2.32 \mathrm{mg} 100 \mathrm{~g}^{-1}\right)$ variety (Table 3). In the study conducted by Abacı and Sevindik [48], it was determined that Uruset variety has the highest antioxidant capacity $\left(73.4 \mathrm{mg} 100 \mathrm{~g} \mathrm{~g}^{-1}\right.$ ), while Limon variety has the lowest

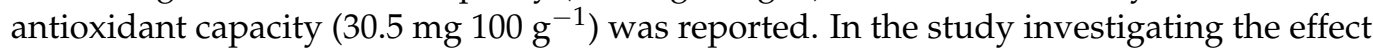
of different applications on the biochemical properties of apple fruits, it was noted that the antioxidant capacity varied between $110.1-491.7 \mu \mathrm{mol}$ TE $100 \mathrm{~g}^{-1}$ [50,51]. Researchers reported that the antioxidant activity of three apple varieties grown in the Uttarakhand (West Himalaya) region of India varied between 4.99 and $14.06 \mathrm{mmol} \mathrm{kg}^{-1}$. When the vitamin $C$ content was examined in this study, it was determined that the fruits of the Yeşil (7.66 mg $100 \mathrm{~g}^{-1}$ ) variety contain higher levels of vitamin $C$ than the other varieties. Markowski et al. [52] reported that the amount of vitamin $C$ in French apple varieties ranged from $5.1 \mathrm{mg} 100 \mathrm{~g}^{-1}$ (cv. Judor) to $7.3 \mathrm{mg} 100 \mathrm{~g}^{-1}$ (cv. Ariane). Loncacic and Pilizota [53] stated that the vitamin C content in Golden Tasty and Gold Rush apple 


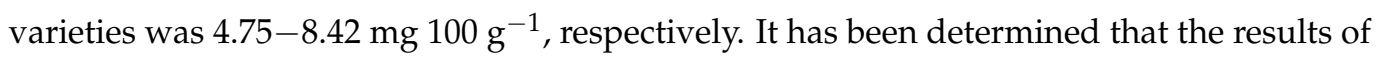
vitamin $C$ obtained in studies by different investigators are in line with our findings $[54,55]$.

\subsection{Nutrients}

Statistically significant differences were determined between apple varieties examined in terms of macronutrients $(\mathrm{N}, \mathrm{P}, \mathrm{K}, \mathrm{Ca}, \mathrm{Mg})$ and micronutrients $(\mathrm{Cu}, \mathrm{Fe}, \mathrm{Mn}, \mathrm{Zn})$ contents $(p<0.05)$. The amount of $\mathrm{N}$ (nitrogen) in fruits ranked between $6533.33 \mathrm{ppm}$ ("Yeşil") and $1733.33 \mathrm{ppm}$ ("Yaz"). It was determined that the amount of $\mathrm{P}$ (phosphorus) ranged from $1017.22 \mathrm{mg} \mathrm{kg}-1$ ("Bağ" and "Zuza") to $639.10 \mathrm{mg} \mathrm{kg}^{-1}$ ("Yaz"), the amount of K (potassium) ranged from $8059.45 \mathrm{mg} \mathrm{kg}^{-1}$ ("Köşeli") to $5752.72 \mathrm{mg} \mathrm{kg}^{-1}$ ("Süt"), the amount of Ca (calcium) ranged from $655.93 \mathrm{mg} \mathrm{kg}^{-1}$ ("Sü" $\mathrm{t}$ ) to $217.06 \mathrm{mg} \mathrm{kg}^{-1}$ ("Beray") and the amount of $\mathrm{Mg}$ (magnesium) ranged from $448.19 \mathrm{mg} \mathrm{kg}^{-1}$ ("Bag") to $206.24 \mathrm{mg} \mathrm{kg}^{-1}$ ("Yaz"). In this study was recorded that content of $\mathrm{Cu}$ (copper) ranged from $3.78 \mathrm{mg} \mathrm{kg}^{-1}$ ("Süt") to $0.74 \mathrm{mg} \mathrm{kg}^{-1}$ ("Zuza"), $\mathrm{Fe}$ (iron) content ranged from $14.17 \mathrm{mg} \mathrm{kg}^{-1}$ ("Zuza") to $5.75 \mathrm{mg} \mathrm{kg}^{-1}$ (Bağ), $\mathrm{Mn}$ (manganese) content ranged from $4.89 \mathrm{mg} \mathrm{kg}^{-1}$ (Bağ) to1.15 $\mathrm{mg} \mathrm{kg}^{-1}$ ("Yaz"), Zn (Zinc) content ranged from $9.41 \mathrm{mg} \mathrm{kg}^{-1}$ (“Süt”) to $2.73 \mathrm{mg} \mathrm{kg}^{-1}$ ("Yaz") ( Tables 4 and 5).

Table 4. Macro elements contents of apple varieties $\left(\mathrm{mg} \mathrm{kg}^{-1}\right)$.

\begin{tabular}{cccccc}
\hline Varieties & $\mathbf{N}$ & $\mathbf{C a}$ & $\mathbf{K}$ & $\mathbf{P}$ & $\mathbf{M g}$ \\
\hline Bă̆ & $5033.33 \pm 145.30 \mathrm{~b}^{*}$ & $244.93 \pm 0.68 \mathrm{f}$ & $7993.31 \pm 64.85 \mathrm{a}$ & $1017.22 \pm 6.19 \mathrm{a}$ & $448.19 \pm 3.67 \mathrm{a}$ \\
Beray & $2000.00 \pm 57.74 \mathrm{f}$ & $217.06 \pm 1.01 \mathrm{~g}$ & $6667.33 \pm 61.31 \mathrm{c}$ & $855.21 \pm 1.19 \mathrm{~b}$ & $280.10 \pm 0.50 \mathrm{f}$ \\
Köşeli & $3100.00 \pm 77.74 \mathrm{~d}$ & $305.29 \pm 3.38 \mathrm{~d}$ & $8059.45 \pm 84.76 \mathrm{a}$ & $680.03 \pm 3.34 \mathrm{~d}$ & $325.85 \pm 0.97 \mathrm{~d}$ \\
Süt & $4433.33 \pm 140.19 \mathrm{c}$ & $655.93 \pm 2.65 \mathrm{a}$ & $5752.72 \pm 12.36 \mathrm{~d}$ & $762.84 \pm 8.98 \mathrm{c}$ & $417.75 \pm 2.36 \mathrm{~b}$ \\
Uzun & $2384.00 \pm 116.57 \mathrm{e}$ & $373.61 \pm 0.64 \mathrm{~b}$ & $7300.11 \pm 47.29 \mathrm{~b}$ & $697.00 \pm 8.05 \mathrm{~d}$ & $312.11 \pm 2.07 \mathrm{e}$ \\
Yaz & $1733.33 \pm 160.19 \mathrm{f}$ & $216.26 \pm 1.40 \mathrm{~g}$ & $6728.99 \pm 42.42 \mathrm{c}$ & $639.10 \pm 3.27 \mathrm{f}$ & $206.24 \pm 0.41 \mathrm{~g}$ \\
Yeşil & $6533.33 \pm 143.19 \mathrm{a}$ & $271.51 \pm 1.40 \mathrm{e}$ & $5771.38 \pm 29.36 \mathrm{~d}$ & $746.74 \pm 5.62 \mathrm{c}$ & $382.56 \pm 1.69 \mathrm{c}$ \\
Zuza & $2800.00 \pm 115.47 \mathrm{~d}$ & $359.76 \pm 1.64 \mathrm{c}$ & $7983.31 \pm 77.29 \mathrm{a}$ & $657.60 \pm 4.03 \mathrm{e}$ & $307.89 \pm 2.72 \mathrm{e}$ \\
\hline
\end{tabular}

* The difference among the means indicated with the same lower case letter in columns was not significant $(p \leq 0.05)$.

Table 5. Micro elements contents of apple varieties $\left(\mathrm{mg} \mathrm{kg}^{-1}\right)$.

\begin{tabular}{ccccc}
\hline Varieties & $\mathbf{C u}$ & $\mathbf{F e}$ & $\mathbf{M n}$ & Zn \\
\hline Bağ & $2.03 \pm 0.01 \mathrm{~d}^{*}$ & $5.75 \pm 0.04 \mathrm{~h}$ & $4.89 \pm 0.05 \mathrm{a}$ & $2.93 \pm 0.04 \mathrm{~g}$ \\
Beray & $1.51 \pm 0.01 \mathrm{f}$ & $8.22 \pm 0.06 \mathrm{f}$ & $1.55 \pm 0.01 \mathrm{~g}$ & $5.66 \pm 0.01 \mathrm{e}$ \\
Köşeli & $1.85 \pm 0.01 \mathrm{e}$ & $13.28 \pm 0.05 \mathrm{~b}$ & $2.19 \pm 0.06 \mathrm{e}$ & $6.42 \pm 0.15 \mathrm{~b}$ \\
Süt & $3.78 \pm 0.01 \mathrm{a}$ & $11.83 \pm 0.13 \mathrm{~d}$ & $1.83 \pm 0.11 \mathrm{f}$ & $9.41 \pm 0.04 \mathrm{a}$ \\
Uzun & $3.60 \pm 0.04 \mathrm{~b}$ & $10.69 \pm 0.05 \mathrm{e}$ & $2.60 \pm 0.09 \mathrm{c}$ & $5.82 \pm 0.01 \mathrm{~d}$ \\
Yaz & $0.76 \pm 0.05 \mathrm{~g}$ & $6.71 \pm 0.05 \mathrm{~g}$ & $1.15 \pm 0.02 \mathrm{~h}$ & $2.73 \pm 0.01 \mathrm{~h}$ \\
Yeşil & $2.29 \pm 0.01 \mathrm{c}$ & $12.74 \pm 0.12 \mathrm{c}$ & $2.27 \pm 0.01 \mathrm{~d}$ & $6.11 \pm 0.01 \mathrm{c}$ \\
Zuza & $0.74 \pm 0.01 \mathrm{~g}$ & $14.17 \pm 0.06 \mathrm{a}$ & $2.85 \pm 0.02 \mathrm{~b}$ & $5.17 \pm 0.03 \mathrm{f}$ \\
\hline
\end{tabular}

* The difference among the means indicated with the same lower case letter in columns was not significant $(p \leq 0.05)$.

In the study conducted by Uçgun et al. [56], the highest values in terms of $\mathrm{N}$ content were found in Starking Delicious (0.36\%) and the lowest values in Long Egg and Batum $(0.26 \%)$ cultivars. The same researchers noted that the P ratio ranged from $0.07 \%$ to $0.05 \%$, the Ca ratio ranged from $0.07 \%$ to $0.04 \%$, and the $\mathrm{Mg}$ ratio ranged from $0.03 \%$ to $0.04 \%$. In a different study, it was reported that the $\mathrm{K}$ ratio was $160.3 \mathrm{mg} 100 \mathrm{~g}^{-1} \mathrm{fw}$, the $\mathrm{Mg}$ ratio was $27.53 \mathrm{mg} 100 \mathrm{~g}^{-1} \mathrm{fw}$ and the Ca ratio was $13.39 \mathrm{mg} 100 \mathrm{~g} \mathrm{fw}$ in the examined apple peel [57]. It is thought that the findings in this study show similarities or differences with the results of different researchers, and the biochemical variation that occurs in fruits is due to genetic, ecological, rootstocks and cultural process differences [58,59].

\subsection{Correlation Results}

Principal component analysis (PCA) is an effective method to determine which features are more critical and descriptive in the data set. The primary purpose of PCA is to 
minimize the number of influencing factors while segregating individuals. Due to this superior feature, it has been frequently used in breeding and population genetics studies in recent years [60-64]. In the study, PCA analysis was performed to determine the correlation between biochemical, agro-morphological characteristics of fruits and varieties. As a result of the analysis, it was seen that the rate of variation between the examined varieties and their characteristics was $51 \%$ (Figure 1). In the research, it was seen that apple varieties were classified in four different regions. It was determined that Süt, Kösseli and Uzun varieties were located in the first region, Yeşil and Bağ varieties in the second region, Yaz and Beray varieties in the third region and Zuza varieties in the fourth region. When apple varieties were evaluated in terms of biochemical and agro-morphological characteristics, it was determined that there was a close correlation between Yeşil and Bağ varieties. It was observed that the Zuza variety has a distinct feature from other varieties. In the study, it was observed that Yeşil and Bağ varieties came to the fore in terms of $\mathrm{Mg}, \mathrm{P}, \mathrm{N}$, Vitamin C, $\mathrm{Mn}$ and antioxidant capacity (DPPH) values. The highest FWD, FL, TP, Zn, Ca, Cu and pH values were determined in Süt, Köşeli, and Uzun varieties. It was observed that the Yaz and Beray varieties were prominent in terms of FW and TSS values, while the Zuza variety came to the fore in terms of $\mathrm{K}, \mathrm{AD}$ and Fe (Figure 1). In this study, when the correlation between biochemical and agro-morphological properties was examined, it was observed that there was a positive correlation between vitamin $\mathrm{C}$ and $\mathrm{DPPH}, \mathrm{N}, \mathrm{Mg}, \mathrm{P}$ and $\mathrm{Cu}$ and the values were $r=0.67, r=0.63, r=0.52, r=0.54$ and $r=0.48$, respectively (Figure 2). It was determined that there was a negative correlation between the total antioxidant activities (DPPH) of fruits and Ca and FWD and the values were $r=-0.54$ and $r=-0.55$, respectively.

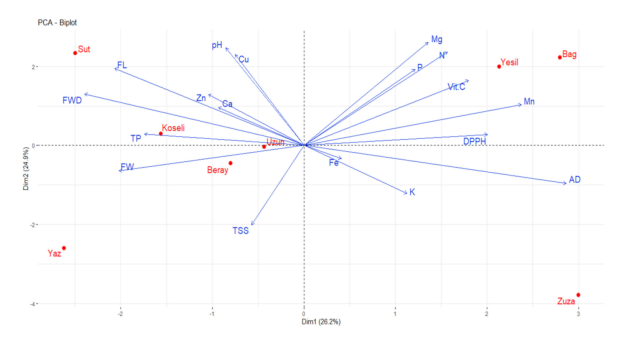

Figure 1. Determining the statistical distribution of apple varieties according to their biochemical and agro-morphological characteristics and the change between them by PCA analysis. FW (Fruit weight), FWD (Fruit width), FL (Fruit length), AD (Acidity), TSS (Total soluble solid), Vit. C (Vitamin C), TP (Total phenolic), DPPH (1,1-diphenyl-2-picrylhydrazyl), N (Nitrogen), P (Phosphorus), K (Potassium), Ca (Calcium), Mg (Magnesium), Fe (Iron), Zn (Zinc), Cu (Copper), Mn (Manganese).

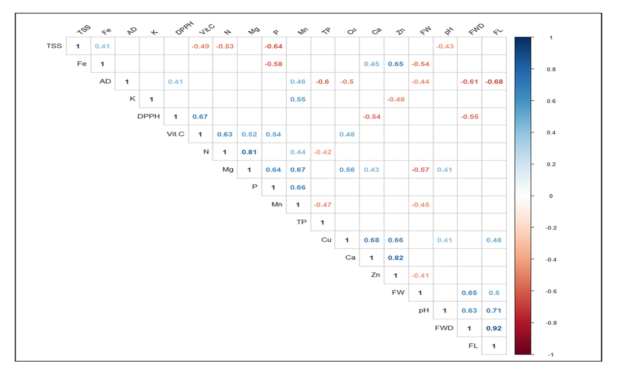

Figure 2. Correlation between biochemical and agro-morphological properties. Correlations in the empty fields were found to be close to zero and insignificant. FW (Fruit weight), FWD (Fruit width), FL (Fruit length), AD (Acidity), TSS (Total soluble solid), Vit. C (Vitamin C), TP (Total phenolic), DPPH (1,1-diphenyl-2-picrylhydrazyl), N (Nitrogen), P (Phosphorus), K (Potassium), Ca (Calcium), $\mathrm{Mg}$ (Magnesium), Fe (Iron), Zn (Zinc), Cu (Copper), Mn (Manganese).

\section{Conclusions}

According to the results obtained in the study, "Köşeli" and "Yaz" varieties in terms of pomological properties, "Yeşil" variety in terms of bioactive compounds and "Bağ" and 


\begin{abstract}
"Süt" varieties came to the fore in terms of nutritional elements. "The highest antioxidant activity and vitamin C content were determined in "Yeşil" variety. Total phenolic compound, which is an important criterion in fields such as fruit juice and pharmaceutical industry, was found in the highest "Beray" variety. In the light of the findings obtained in the study, it was seen that the fruits of these local varieties are rich in nutritional content. It was determined that "Yeşil" and "Bă̆" varieties formed similar correlations in terms of biochemical content, while "Zuza" variety showed a different character. In addition, it was observed that the total antioxidant activity created a strong positive correlation with vitamin C. These apple varieties, which are newly selected as a result of breeding studies, are important in terms of conserving genetic diversity, providing materials for future breeding studies and developing apple genetic resources. Therefore, it is necessary to expand such research in order to protect the cultivated apple varieties and to improve the world's biodiversity. In this study, there has been no previous research on apple varieties examined. As a result of the selection of local apple genetic resources, genotypes that have promising characteristics in terms of pomological and biochemical features were protected by creating a genetic plot in the Samsun region. In this respect, the study is important for the protection and development of the world's apple genetic resources.
\end{abstract}

Supplementary Materials: The following are available online at https://www.mdpi.com/article/10 $.3390 /$ su13116127/s1, Table S1: Temperature data of the province of Artvin for 2017, 2018 and 2019 years. Table S2: Sunshine, relative humidity, and total precipitation data of Artvin province for 2017, 2018 and 2019 years.

Author Contributions: Conceptualization, I.M., E.A. and M.G.; data curation, I.M. and E.A.; formal analysis, İ.M.; E.A. and A.T.; methodology, İ.M., E.A. and A.T.; M.G. visualization, M.G., E.A., İ.M. and A.T.; writing-original draft, M.G., E.A., İ.M. and A.T.; writing-review and editing, İ.M., E.A. and A.T. All authors have read and agreed to the published version of the manuscript.

Funding: The authors received no financial support for the research, authorship, and/or publication of this article.

Institutional Review Board Statement: Not applicable.

Informed Consent Statement: Not applicable.

Data Availability Statement: All new research data were presented in this contribution.

Conflicts of Interest: The authors declare that they have no conflict of interest.

\title{
References
}

1. Ercisli, S.; Esitken, A.; Cangi, R.; Sahin, F. Adventitious root formation of kiwifruit in relation to sampling date, IBA and Agrobacterium rubi inoculation. Plant Growth Regul. 2003, 41, 133-137. [CrossRef]

2. Kaya, T.; Balta, F. Apple selection in Van province. J. Agric. Sci. 2013, 2, 91-98.

3. Dogan, H.; Ercisli, S.; Jurikova, T.; Temim, E.; Leto, A.; Hadziabulic, A.; Tosun, M.; Narmanlioglu, H.K.; Zia-Ul-Haq, M. Physicochemical and antioxidant characteristics of fruits of cape gooseberry (Physalis peruviana L.) from Turkey. Oxid. Commun. 2014, 37, 1005-1014.

4. Gundogdu, M.; Ozrenk, K.; Ercisli, S.; Kan, T.; Kodad, O.; Hegedus, A. Organic acids, sugars, vitamin C content and some pomological characteristics of eleven hawthorn species (Crataegus spp.) from Turkey. Biol. Res. 2014, 47, 21. [CrossRef]

5. Eyduran, S.P.; Akin, M.; Ercisli, S.; Eyduran, E.; Magharadze, D. Sugars, organic acids, and phenolic compounds of ancient grape cultivars (Vitis vinifera L.) from Igdir province of Eastern Turkey. Biol. Res. 2015, 48, 2. [CrossRef]

6. Karatas, N.; Sengul, M. Some important physicochemical and bioactive characteristics of the main apricot cultivars from Turkey. Turk. J. Agric. For. 2020, 44, 651-661. [CrossRef]

7. Çaliskan, O.; Bayazit, S.; Oktem, M.; Ergul, A. Evaluation of the genetic diversity of pomegranate accessions from Turkey using new microsatellite markers. Turk. J. Agric. For. 2017, 41, 142-153. [CrossRef]

8. Engin, S.P.; Mert, C. The effects of harvesting time on the physicochemical components of aronia berry. Turk. J. Agric. For. 2020, 44, 361-370. [CrossRef]

9. Geçer, M.K.; Ozkan, G.; Sagbas, H.I.; Ilhan, G.; Gundogdu, M.; Ercisli, S. Some important horticultural properties of summer apple genotypes from Coruh Valley in Turkey. Int. J. Fruit Sci. 2020, 20, S1406-S1416. [CrossRef]

10. Kschonsek, J.; Wolfram, T.; Stöckl, A.; Böhm, V. Polyphenolic compounds analysis of old and new apple cultivars and contribution of polyphenolic profile to the in vitro antioxidant capacity. Antioxidants 2018, 7, 20. [CrossRef] 
11. Sampath, C.; Rashid, M.R.; Sang, S.; Ahmedna, M. Specific bio active compounds in ginger and apple all evia tehyp ergly cemia in mice with high fat diet-induced obesity via Nrf2 media tepath way. Food Chem. 2017, 226, 79-88. [CrossRef]

12. Opyd, P.M.; Jurgoński, A.; Juśkiewicz, J.; Milala, J.; Zduńczyk, Z.; Król, B. Nutritional and health-related effects of a diet containing apple seed meal in rats: The case of amygdalin. Nutrients 2017, 9, 1091. [CrossRef]

13. Li, R.; Wenli, Z.; Jingxia, W.; Hongwu, W.; Ye, Z.; Yiider, T.; Huaien, B. Extra dose of vitamin C based on a daily supplementation shortens the common cold: A meta-analysis of 9 randomized controlled trials. Biomed. Res. Int. 2018, 2018, 12.

14. Chen, A.Y.; Chen, Y.C. A review of the dietary flavonoid, kaempferol on human health and cancer chemoprevention. Food Chem. 2013, 138, 2099-2107. [CrossRef]

15. Jia, N.; Xiong, Y.L.; Kong, B.; Liu, Q.; Xia, X. Radical scavenging activity of black currant (Ribes nigrum L.) extract and its inhibitory effect on gastric cancer cell proliferation via induction of apoptosis. J. Funct. Food. 2012, 4, 382-390. [CrossRef]

16. Gündoğdu, M.; Muradoglu, F.; Gazioglu Sensoy, R.I.; Y1lmaz, H. Determination of fruit chemical properties of Morus nigra L., Morus alba L. and Morus rubra L. by HPLC. Sci. Hortic. 2011, 132, 37-41. [CrossRef]

17. Gündoğdu, M.; Yılmaz, H. Organic acid, phenolic profile and antioxidant capacities of pomegranate (Punica granatum L.) cultivars and selected genotypes. Sci. Hortic. 2012, 143, 38-42. [CrossRef]

18. Wolfe, K.L.; Liu, R.H. Apple peels as a value-added food ingredient. J. Agric. Food Chem. 2003, 51, 1676-1683. [CrossRef]

19. Jakobek, L.; Ištuk, J.; Buljeta, I.; Voća, S.; Žlabur, J.Š.; Babojelić, M.S. Traditional, Indigenous apple varieties, a fruit with potential for beneficial effects: Their quality traits and bioactive polyphenol contents. Foods 2020, 9, 52. [CrossRef]

20. Reig, G.; Blanco, A.; Castillo, A.M.; Gogorcena, Y.; Moreno, M.A. Phenotypic diversity of Spanish apple (Malus $x$ domestica Borkh) accessions grown at the vulnerable climatic conditions of the Ebro Valley, Spain. Sci. Hortic. 2015, 185, 200-210. [CrossRef]

21. Font i Forcada, C.; Reig, G.; Mestre, L.; Mignard, P.; Betrán, J.Á.; Moreno, M.Á. Scion $\times$ Rootstock Response on Production, Mineral Composition and Fruit Quality under Heavy-Calcareous Soil and Hot Climate. Agronomy 2020, 10, 1159. [CrossRef]

22. Coşkun, S.; Aşkın, M.A. Bazı yerli elma çesitlerinin pomolojik ve biyokimyasal özelliklerinin belirlenmesi. Süleyman Demirel Üni. Zir. Fak. Derg. 2016, 11, 120-131.

23. Bramlage, W.J. Interactions of orchard factors and mineral nutrition on quality of pome fruit. Acta Hort. 1993, 326, 15-28. [CrossRef]

24. Noe', N.; Eccher, T.; Porro, D.; Stainer, R. Quality of Golden Delicious apples as affected by season and by nitrogen and potassium mineral nutrition. Acta Hort. 1997, 448, 487-497. [CrossRef]

25. Fallahi, E.; Simons, B.R. Interrelations among leaf and fruit mineral nutrients and fruit quality in “Delicious" apples. J. Tree Fruit Prod. 1996, 1, 15-25. [CrossRef]

26. Tomala, K. Orchard factors affecting nutrient content and fruit quality. Acta Hort. 1997, 448, 257-264. [CrossRef]

27. Dris, R.; Niskanen, R. Leaf and fruit macronutrient composition during the growth period of apples. J. Food Agric. Environ. 2004, 2, 174-176.

28. McGhie, T.K.; Hunt, M.; Barnett, L.E. Cultivar and growing region determine the antioxidant polyphenolic concentration and composition of apples grown in New Zeland. J. Agric. Food Chem. 2005, 53, 3065-3070. [CrossRef]

29. GDM. General Directorate of Meteorology. In Meteorological Data Archive and Management System; Station no 17045; Meteorology 11th Regional Directorate: Artvin, Turkey, 2021.

30. Horneck, D.A.; Miller, R.O. Determination of total nitrogen in plant tissue. In Handbook of Reference Methods for Plant Analysis; CRC Press: Boca Raton, FL, USA, 1998; Volume 2, pp. 75-83.

31. Kacar, B. Bitki Besleme Uygulama Kılavuzu. In Ankara Üniversitesi Ziraat Fakültesi Yayınları: 900; Uygulama Kılavuzu: Ankara, Turkey, 1984; p. 140.

32. Molyneux, P. The use of the stable free radical diphenylpicrylhydrazyl (DPPH) for estimating antioxidant activity. Songklanakarin J. Sci. Technol. 2004, 26, 211-219.

33. Singleton, V.L.; Rossi, J.A. Calorimetry of total phenolics with phosphomolybdic-phosphotungstic acid reagent. Am. J. Enol. Vitic. 1965, 16, 144-158.

34. Cemeroglu, B. Food Analysis. Food Technol. Soc. Publ. 2007, 34, 168-171.

35. Wickham, H. ggplot2: Elegant Graphics for Data Analysis; Springer: New York, NY, USA, 2016; ISBN 978-3-319-24277-4.

36. Ruttanaprasert, R.; Banterng, P.; Jogloy, S.; Vorasoot, N.; Kesmala, T.; Kanwar, R.S.; Holbrook, C.C.; Patanothai, A. Genotypic variability for tuber yield, biomass, and drought tolerance in Jerusalem artichoke germplasm. Turk. J. Agric. For. 2014, 38, 570-580. [CrossRef]

37. Rezaeirad, D.; Bakhshi, D.; Ghasemnezhad, M.; Lahiji, H.S. Evaluation of some quantitative and qualitative characteristics of local pears (Pyrus sp.) in the North of Iran. Int. J. Agric. 2013, 5, 882-887.

38. Öztürk, A.; Öztürk, B. Samsun ekolojisinde yetiştirilen standart bazı elma çeşitlerinin fenolojik ve pomolojik özelliklerinin belirlenmesi. Anadolu Tarım Bilimleri Derg. 2016, 31, 1-8. [CrossRef]

39. Boyacı, S. Bazı elma (Malus domestica L.) çeşitlerinin fenolojik ve pomolojik özelliklerinin belirlenmesi. Turk. J. Agric. Res. 2019, 6, 73-79.

40. Karşı, T.; Aslantaş, R. Erzurum'da yetiştirilen bazı elma (Malus communis L.) çeşitlerinin fenolojik, pomolojik ve kimyasal özelliklerinin belirlenmesi. Atatürk Univ. J. Agric. Fac. 2016, 47, 11-21.

41. Balta, M.F.; Aksoy, B.; Karakaya, O.; Uzun, S. Çarşamba ekolojik koşullarında yetiştirilen bazı standart elma çeşitlerinin verim ve meyve özellikleri. Akademik Ziraat Dergisi 2020, 9, 187-192. 
42. Gundogdu, M.; Canan, I.; Okatan, V. Bioactive contents and some horticultural characteristics of local apple genotypes from Turkey. The J. Anim. Plant Sci. 2018, 28, 865-874.

43. Hajnajari, H.; Kohneshine Leily, H.; Bakhshi, D. Selection of promising early ripening progenies and assessment of earliness heritability in the breeding program of apple. Agric. Conspec. Sci. 2019, 84, 245-256.

44. Öztürk, B.; Uzun, S.; Bektaş, E.; Yarılgaç, T.; Karakaya, M.; Karakaya, M.; Gün, S.; Turga, E. M9 Anacı üzerine aşılı bazı elma çeşitlerinin Ordu ilinde verim ve kalite özelliklerinin belirlenmesi. Bahçe 2016, 45, 492-497.

45. Khanizadeh, S.; Tsao, R.; Rekika, D.; Yang, R.; Deell, J. Phenolic composition and antioxidant activity of selected apple genotypes. J. Food Agric. Environ. 2007, 5, 61-66.

46. Michailidis, M.; Karagiannis, E.; Nasiopoulou, E.; Skodra, C.; Molassiotis, A.; Tanou, G. Peach, Apple, and Pear Fruit Quality: To Peel or Not to Peel? Horticulturae 2021, 7, 85. [CrossRef]

47. Karagiannis, E.; Michailidis, M.; Tanou, G.; Scossa, F.; Sarrou, E.; Stamatakis, G.; Samiotaki, M.; Martens, S.; Fernie, A.R.; Molassiotis, A. Decoding altitude-activated regulatory mechanisms occurring during apple peel ripening. Hortic. Res. 2020, 7, 120. [CrossRef]

48. Bouayed, J.; Hoffmann, L.; Bohn, T. Total phenolics, flavonoids, anthocyanins and antioxidant activity following simulated gastro-intestinal digestion and dialysis of apple varieties: Bioaccessibility and potential uptake. Food Chem. 2011, 128, 14-21. [CrossRef]

49. Abacı, Z.T.; Sevindik, E. Ardahan bölgesinde yetiştirilen elma çeşitlerinin biyoaktif bileşiklerinin ve toplam antioksidan kapasitesinin belirlenmesi. YYU Tarm Bilimleri Derg. 2014, 24, 175-184.

50. Kevers, C.; Pincemail, J.; Tabart, J.; Defraigne, J.-O.; Dommes, J. Influence of cultivar, harvest time, storage conditions, and peeling on the antioxidant capacity and phenolic and ascorbic acid contents of apples and pears. J. Agric. Food Chem. 2011, 59, 6165-6171. [CrossRef]

51. Bahukhandı, A.; Dhyanı, P.; Bhatt, I.D.; Rawal, R.S. Variation in polyphenolics and antioxidant activity of traditional apple cultivars from West Himalaya, Uttarakhand. Hortic. Plant J. 2018, 4, 151-157. [CrossRef]

52. Markowsk1, J.; Baron, A.; Mieszczakowska, M.; Płocharskı1, W. Chemical composition of French and Polish cloudy apple juices. J. Hortic. Sci. 2009, 68-74. [CrossRef]

53. Loncacic, A.; Pilizota, V. 2014. Effect of variety, growing season and storage on polyphenol profile and antioxidant activity of apple peels. Sci. J. Nutr. Diet. 2014, 3, 96-105.

54. Bianchi, F.; Soini, E.; Ciesa, F.; Bortolotti, L.; Guerra, W.; Robatscher, P.; Oberhuber, M. L-ascorbic acid and $\alpha$-tocopherol content in apple pulp: A comparison between 24 cultivars and annual variations during three harvest seasons. Int. J. Food Prop. 2020, 23, 1624-1638. [CrossRef]

55. Lemmensa, E.; Alós, E.; Rymenantsa, M.; Storme, N.D.; Keulemansa, W.J. Dynamics of ascorbic acid content in apple (Malus $x$ domestica) during fruit development and storage. Plant Physiol. Biochem. 2020, 151, 47-59. [CrossRef]

56. Uçgun, K.; Akgül, H.; Özongun, S.; Altındal, M.; Kaymak, S. Bazı Elma Tip ve Çesitlerinde "Elma Kara Leke” Hastalıgına (Venturia inaequalis (Cke) Wint) Dayanıklılık Mekanizmasının Bitki Besin Elementleri Yönünden İncelenmesi. Meyve Bilimi. 2015, 2, 22-26.

57. Rafaella, P.; Anna, M.T. Study of polyphenols, antioxidant capacity and minerals for the valorisation of ancient apple cultivars from Northeast Italy. Eur. Food Res. Technol. 2021, 247, 273-283.

58. Ercisli, S.; Esitken, A.; Turkkal, C.; Orhan, E. The allelopathic effects of juglone and walnut leaf extracts on yield, growth, chemical and PNE compositions of strawberry cv. Fern. Plant Soil Environ. 2005, 51, 283-287. [CrossRef]

59. Bolat, I.; Dikilitas, M.; Ercisli, S.; Ikinci, A.; Tonkaz, T. The effect of water stress on some morphological, physiological, and biochemical characteristics and bud success on apple and quince rootstocks. Sci. World J. 2014, 76, 9732. [CrossRef]

60. Dogan, H.; Ercisli, S.; Temim, E.; Hadziabulic, A.; Tosun, M.; Yilmaz, S.O.; Zia-Ul-Haq, M. Diversity of chemical content and biological activity in flower buds of a wide number of wild grown caper (Capparis ovate Desf.) genotypes from Turkey. Comptes Rendus Acad. Bulg. Sci. 2014, 67, 1593-1600.

61. Gecer, M.K.; Kan, T.; Gundogdu, M.; Ercisli, S.; Ilhan, G.; Sagbas, H.I. Physicochemical characteristics of wild and cultivated apricots (Prunus armeniaca L.) from Aras valley in Turkey. Genet. Resour. Crop Evol. 2020, 67, 935-945. [CrossRef]

62. Hashemi, S.M.; Khadivi, A. Morphological variability of Prunus lycioides Spach germplasm using multivariate analysis. Sci. Hortic. 2020, 261, 108973. [CrossRef]

63. Kaskoniene, V.; Bimbiraite-Surviliene, K.; Kaskonas, P.; Tiso, N.; Cesoniene, L.; Daubaras, R.; Maruska, A. S. Changes in the biochemical compounds of Vaccinium myrtillus, Vaccinium vitis-idaea, and forest litter collected from various forest types. Turk. J. Agric. For. 2020, 44, 557-566. [CrossRef]

64. Kupe, M. Some ampelographic and biochemical characteristics of local grape accessions from Turkey. Genetika 2020, 50, 513-525. [CrossRef] 